\title{
Comparative Studies on the Physiobiochemical, Enzymatic, and Ionic Modifications in Salt-tolerant and Salt-sensitive Citrus Rootstocks under NaCl Stress
}

\author{
Rashad M. Balal \\ Department of Horticulture, University College of Agriculture, University of Sargodha, Punjab, \\ 40100, Pakistan
}

\author{
Muhammad M. Khan \\ Institute of Horticultural Sciences, University of Agriculture, Faisalabad, 38040, Punjab, Pakistan \\ Muhammad A. Shahid ${ }^{1}$ and Neil S. Mattson \\ Department of Horticulture, College of Agriculture and Life Sciences, Cornell University, Ithaca, NY 14850 \\ Tahira Abbas \\ Institute of Horticultural Sciences, University of Agriculture, Faisalabad, 38040, Punjab, Pakistan \\ Muhammad Ashfaq \\ Department of Agri-entomology, University of Agriculture, Faisalabad, 38040, Punjab, Pakistan
}

Franscisco Garcia-Sanchez

Dpto. Nutrición Vegetal, Centro de Edafología y Biología aplicada del Segura, CSIC, Campus

Universitario de Espinardo, 30100 Espinardo, Murcia, Spain

\begin{abstract}
Usman Ghazanfer
Department of Plant Pathology, University College of Agriculture, University of Sargodha, Punjab, 40100, Pakistan
\end{abstract}

\section{Vicente Gimeno \\ Dpto. Nutrición Vegetal, Centro de Edafología y Biología aplicada del Segura, CSIC, Campus Universitario de Espinardo, 30100 Espinardo, Murcia, Spain}

\section{Zafar Iqbal}

Department of Plant Pathology, University College of Agriculture, University of Sargodha, Punjab, 40100, Pakistan

\begin{abstract}
AdDitional INDEX wORDs. antioxidants, epidermal cells, stomata, photosynthesis, stomatal conductance, ions
Abstract. A study was conducted to investigate the morphological, physiobiochemical, enzymatic, and ionic differences among four cultivated citrus (Citrus sp.) rootstocks with different salt tolerances. Two salt-tolerant rootstocks [Rangpur lime $(C$. limonia) and Rubidoux $(C$. trifoliata $)$ and two salt-sensitive rootstocks [Carrizo citrange (Citrus sinensis $\times$ $C$. trifoliata) and Sanchton citrumello $(C$. trifoliata $\times C$. paradisi $)]$, were subjected to $\mathrm{NaCl}$ stress in greenhouse conditions. The 9-month-old plants were exposed to four different $\mathrm{NaCl}$ levels $(0,30,60$, or $90 \mathrm{~mm})$ in sand culture for 3 months. Plant biomass (fresh weight, dry weight, root length, shoot length, and leaf thickness), physiological attributes [number of stomata, stomatal size, number of epidermal cells, photosynthesis rate, stomatal conductance $\left(g_{\mathrm{S}}\right)$, water use efficiency, and transpiration rate]. and ion content $\left(\mathrm{Na}^{+}, \mathrm{K}^{+}, \mathrm{Ca}^{+2}, \mathrm{Mg}^{+2}\right.$, and $\left.\mathrm{Cl}^{-}\right)$were adversely affected by salt stress, but salt-tolerant cultivars were comparatively less affected. Salt stress also enhanced antioxidant enzyme activity (superoxide dismutase, catalase, and peroxidase), particularly in salt-tolerant cultivars. The salt-sensitive cultivars accumulated the greatest content of $\mathrm{Na}^{+}$and $\mathrm{Cl}^{-}$in their leaves, whereas the salt-tolerant cultivars accumulated the greatest content of $\mathrm{Na}^{+}$and $\mathrm{Cl}^{-}$in their roots, an adaptation to combat the highly saline conditions. Overall, it was concluded that the salt tolerance of rootstocks is associated with a greater antioxidant enzyme activity and differing accumulation patterns of $\mathrm{Na}^{+}, \mathrm{K}^{+}, \mathrm{Cl}^{-}, \mathrm{Mg}^{+2}$, and $\mathrm{Ca}^{+2}$ in leaves and roots; these can be considered potential indicators of a cultivar's sensitivity to salt stress.
\end{abstract}

Received for publication 14 Nov. 2011. Accepted for publication 1 Feb. 2012. We thank the Higher Education Commission of Pakistan for financial assistance and the Nuclear Institute for Agriculture and Biology for providing the equipment used in this study.

'Corresponding author. E-mail: mas795@cornell.edu or adnanshahid@uaf. edu.pk.
Salinity is a build-up of soluble salts (Levy and Syvertsen, 2004). This build-up causes adverse morphological, physiological, and biochemical effects in different organs of citrus plants through an increased concentration of sodium and chloride (Camara-Zapata et al., 2004; Rachmilevitch et al., 2004; Raveh and Levy, 2005; Romero-Aranda et al., 1998; Zekri, 2004). 
Excess amounts of these salts enhance the osmotic potential $\left(\psi_{\mathrm{S}}\right)$ of the soil matrix, restricting the plant's water intake (Garcia-Sanchez et al., 2002a, 2002b). Plants have developed many adaptive strategies in response to abiotic stresses such as salinity that ultimately influence plant growth and yield (McCue and Hanson, 1990).

Sodium and chloride are major ions and can cause various disorders in citrus plants (Romero-Aranda et al., 1998). Sodium chloride is reported to be a major source of ions in salt solutions compared with $\mathrm{Na}_{2} \mathrm{SO}_{4}$ because $\mathrm{NaCl}$ liberates $\approx 60 \%$ more ions than $\mathrm{Na}_{2} \mathrm{SO}_{4}$ does (Rachmilevitch et al., 2004). Beyond the osmotic effects of salt in the root zone, salt stress causes oxidative stress in plant cells through the generation of reactive oxygen species (ROS), including hydroxyl and superoxide radicals, through various metabolic processes such as photorespiration (Noreen and Ashraf, 2009). Salinity reduces stomatal function and favors the denaturation of chlorophyll (Hernandez et al., 1999), which ultimately leads to a reduction in $g_{S}$, photosynthetic activity, and the generation of free oxygen radicals, thus inducing oxidative stress. ROS can cause toxic reactions such as lipid peroxidation, protein degradation, and DNA mutation (McCord, 2000). In response, a plant may synthesize more antioxidant enzymes (Sairam et al., 2005), including superoxide dismutase (SOD), catalase (CAT), and peroxidase (POD) (Noreen and Ashraf, 2009).

The growth and productivity of citrus plants are inhibited by saline as a result of the ion toxicity of $\mathrm{Na}^{+}$and $\mathrm{Cl}^{-}$as well as the ion antagonisms that occur with $\mathrm{Na}^{+}$and $\mathrm{Cl}^{-}$that limit nutrient availability (Munns and James, 2003). In citrus production, rootstocks are used to control a plant's size and form and play a key role in establishing excellent fruit quality and yield. Rootstocks also may impart a tolerance to various biotic and abiotic factors, thus contributing to higher production (Waqar et al., 2007). In citrus plants, excess salts in the root zone may negatively affect plant morphological features, mineral nutrition, and various physiobiochemical mechanisms; i.e., photosynthesis, $g_{\mathrm{S}}$ and transpiration (Garcia-Sanchez and Syvertsen, 2006; Garcia-Sanchez et al., 2006). Citrus rootstocks may play an important role with regard to the emerging threat of soil salinity. Therefore, the present study was conducted to assess the effect of salt stress on the various physiological and biochemical aspects of salt-tolerant and salt-sensitive citrus rootstocks. The findings of this investigation also clearly demonstrate the differences that occur with respect to various morphological, biochemical, enzymatic, and ionic attributes of salt-tolerant and salt-sensitive citrus rootstocks. The results may indicate the degree to which rootstocks enhance citrus performance under saline conditions and lead to early screening methods to detect tolerant rootstocks.

\section{Materials and Methods}

\section{Plant material and growth conditions}

To study the effect of salinity on citrus rootstock cultivars, a greenhouse experiment was conducted with potted plants and a sand substrate. Two salt-tolerant (Rangpur lime and Rubidoux) and two salt-sensitive (Carrizo citrange and Sanchton citrumello) rootstocks, screened from 10 rootstocks in a preliminary experiment (R.M. Balal, unpublished data) were used. The seeds were sown in nursery beds to grow the rootstock seedlings. The 6-month-old seedlings were carefully removed and transplanted into $30 \times 25-\mathrm{cm}$ black-painted plastic pots filled with $6.5 \mathrm{~kg}$ (4.5 L volume) of Astatula fine sand (hyperthermic, uncoated, Typic Quartzipsamments). The sand was fine with a pH of 6.0 to 6.5 , a field capacity of $7.2 \%$, and a wilting point at $1.2 \%$ moisture content (volume basis) (Camara-Zapata et al., 2004). Pots were placed in a greenhouse with a photoperiod of $16 \mathrm{~h}$ (with incandescent bulbs), temperature of $26 \pm 2{ }^{\circ} \mathrm{C}$, and relative humidity of $70 \%$. The seedlings were watered with modified half-strength Hoagland solution for $90 \mathrm{~d}$ under greenhouse conditions (Hoagland and Arnon, 1950). After the 90-d establishment period, four different levels of $\mathrm{NaCl}(0,30,60$, or $90 \mathrm{~mm})$ were applied to citrus rootstock plants along with half-strength Hoagland solution in the irrigation solution for another $90 \mathrm{~d}$. The seedlings were adjusted to their final $\mathrm{NaCl}$ concentration by gradually increasing the salt concentration by $30 \mathrm{~mm}$ every $2 \mathrm{~d}$ to avoid osmotic shock. The control treatment $(0 \mathrm{~mm})$ received only half-strength Hoagland solution. After the 90-d treatment period, samples of leaves, shoots, and roots were collected for the determination of morphophysiological and biochemical attributes. There were five replicates (an experimental unit was one plant in one pot) per treatment-by-cultivar combination. For each parameter listed subsequently, five replicates were used (i.e., samples were collected from each experimental unit).

\section{Determination of shoot/root biomass and leaf thickness}

For estimation of shoot/root biomass, the plants were harvested carefully from the pots and washed with distilled water. The fresh weights of the roots and shoots were recorded, and the samples were placed in an oven at $70{ }^{\circ} \mathrm{C}$ to determine the dry weight. Leaf thickness was measured with laserilluminated light microscope (Eclipse Ni-E; Nikon, Tokyo, Japan) by using an ocular micrometer (MeCan, Saitama, Japan), whereas the leaf was viewed on a computer monitor through the use of EFD-3 software (Shenzhen Eternal Science, Beijing, China).

\section{Determination of number of stomata, epidermal cells, and stomatal size}

The number of stomata and epidermal cells was counted by separating a very thin abaxial layer $(2 \times 3 \mathrm{~mm})$ from a sample leaf epidermis. This dry layer was carefully separated and placed on the stage of microscope (Eclipse Ni-E with Optiphot-2 eyepiece; Nikon). A drop of water was applied to the dry layer, covered with a microscope slide, and stomata were viewed on a monitor using EFD-3 software. The number of stomata and epidermal cells was counted at a magnification of $40 \times 10\left(1 \mathrm{~mm}^{2}\right.$ had $\approx 20-25$ stomata per slide) (Almansa et al., 2002). The length and width of stomata and epidermal cells were measured in microns with the microscope (Moya et al., 2003).

\section{Determination of photosynthesis, stomatal conductance, transpiration rate, and water use efficiency}

The photosynthetic rate $\left(\mathrm{P}_{\mathrm{n}}\right)$, transpiration $(E)$, and $g_{\mathrm{S}}$ were measured from the second most recently mature healthy young leaf from each plant using a portable infrared gas analyzer (LCA-4 ADC; Analytical Development Co., Hoddesdon, U.K.). All measurements were made during the day between 1000 and $1200 \mathrm{HR}$ with a molar flow of air per unit leaf area of $403.3 \mathrm{mmol} \cdot \mathrm{m}^{-2} \cdot \mathrm{s}^{-1}$, an atmospheric pressure $99.9 \mathrm{kPa}$, a water vapor pressure in the chamber between 0.60 and $0.89 \mathrm{kPa}$, a maximum photosynthetic active radiation at the leaf surface 
Table 1. Correlations among plant dry weight (DW), photosynthesis rate $\left(\mathrm{P}_{\mathrm{n}}\right)$, stomatal conductance $\left(g_{\mathrm{S}}\right)$, transpiration rate $(E)$, number of stomata (NS), stomatal size (SS), water use efficiency (WUE), superoxide dismutase (SOD), peroxidase (POD), catalase (CAT), leaf sodium content, and leaf chloride content of four citrus rootstocks grow under salt stress.

\begin{tabular}{|c|c|c|c|c|c|c|c|c|c|c|c|c|}
\hline & DW & $P_{n}$ & $g_{\mathrm{S}}$ & $E$ & NS & SS & WUE & SOD & POD & CAT & Leaf $\mathrm{Na}$ & Leaf $\mathrm{Cl}$ \\
\hline$\overline{\mathrm{DW}}$ & 1 & & & & & & & & & & & \\
\hline$P_{n}$ & 0.93 & 1 & & & & & & & & & & \\
\hline$g_{\mathrm{S}}$ & 0.87 & 0.84 & 1 & & & & & & & & & \\
\hline NS & 0.82 & 0.93 & 0.74 & 0.84 & 1 & & & & & & & \\
\hline SS & 0.67 & 0.81 & 0.67 & 0.76 & 0.23 & 1 & & & & & & \\
\hline WUE & 0.9 & 0.95 & 0.54 & 0.86 & 0.64 & 0.68 & 1 & & & & & \\
\hline POD & 0.63 & 0.63 & 0.38 & 0.45 & 0.31 & 0.29 & 0.48 & 0.21 & 1 & & & \\
\hline CAT & 0.79 & 0.48 & 0.47 & 0.57 & 0.29 & 0.33 & 0.63 & 0.25 & 0.19 & 1 & & \\
\hline Leaf $\mathrm{Na}$ & -0.91 & -0.87 & -0.77 & -0.95 & -0.68 & -0.71 & 0.59 & 0.91 & 0.84 & 0.76 & 1 & \\
\hline Leaf Cl & -0.89 & -0.76 & -0.84 & -0.91 & -0.73 & -0.66 & 0.72 & 0.94 & 0.91 & 0.88 & 0.21 & 1 \\
\hline
\end{tabular}

$\mathrm{Na}=$ sodium; $\mathrm{Cl}=$ chloride.
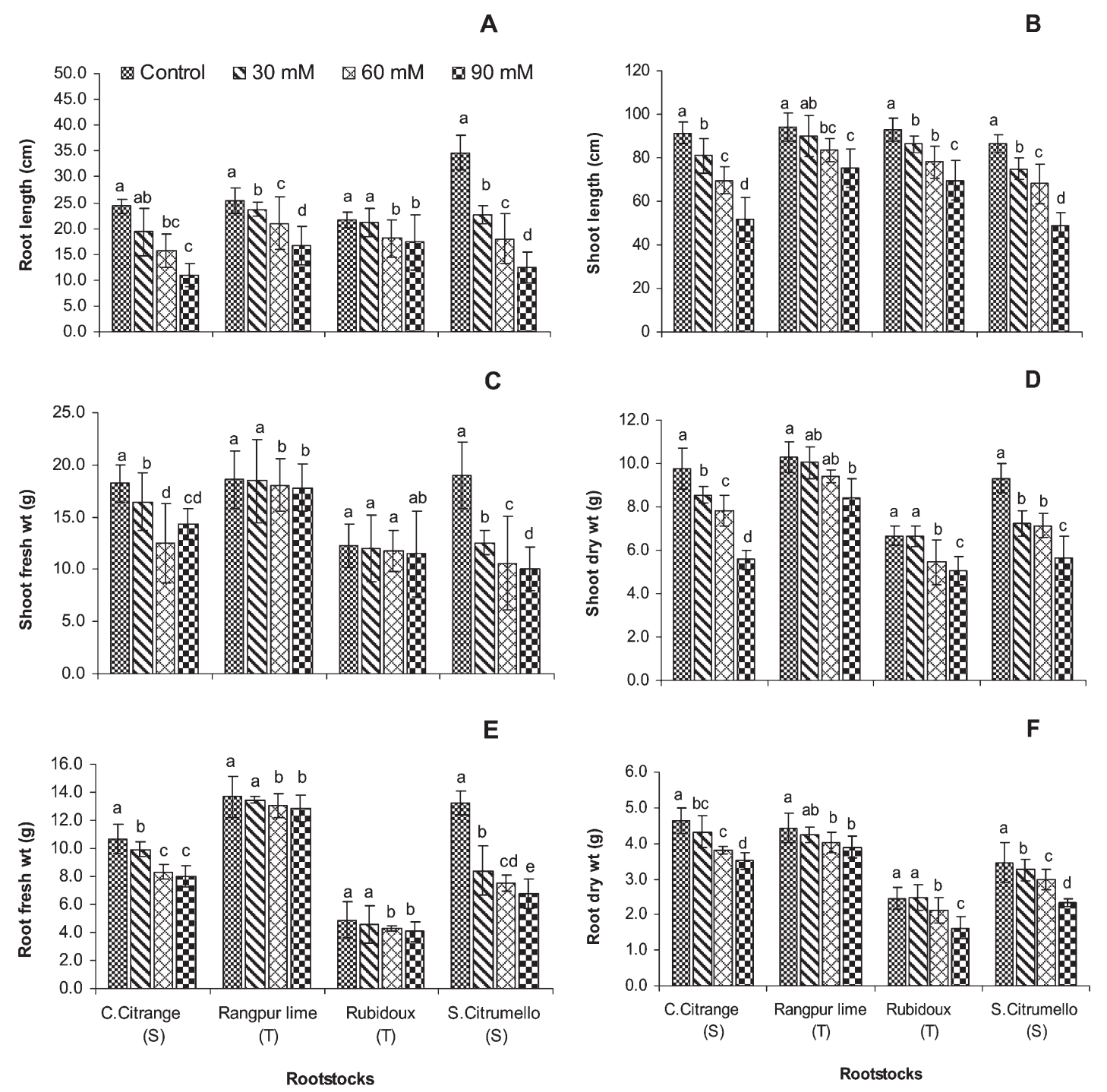

Fig. 1. Effect of salt stress $(0,30,60$, or $90 \mathrm{~mm} \mathrm{NaCl}$ applied in the irrigation water) on plant biomass of two salt-tolerant (T) and two salt-sensitive (S) cultivated citrus rootstocks: root length $(\mathbf{A})$, shoot length $(\mathbf{B})$, shoot fresh weight $(\mathbf{C})$, shoot dry weight $(\mathbf{D})$, root fresh weight $(\mathbf{E})$, and root dry weight $(\mathbf{F})$. Each value represents the mean of five replicates \pm SE. Two-way analysis of variance for the interaction of cultivar $\times$ treatment and main effects of cultivar and treatment were significant at $P<0.05$. Letters within a cultivar represent mean separation comparison using Tukey's honestly significant difference (HSD) test $(\mathrm{C}$. citrange $=$ Carrizo citrange, S. citrumello $=$ Sanchton citrumello). 
of $1711 \mu \mathrm{mol} \cdot \mathrm{m}^{-2} \cdot \mathrm{s}^{-1}$, a leaf temperature between 28.4 and $32.4{ }^{\circ} \mathrm{C}$, an ambient temperature between 22.4 and $27.9^{\circ} \mathrm{C}$, and an ambient $\mathrm{CO}_{2}$ concentration of $352 \mu \mathrm{mol} \cdot \mathrm{mol}^{-1}$. The water use efficiency (WUE) was calculated using the formula: $\mathrm{WUE}=\mathrm{P}_{\mathrm{n}} / E$.

\section{Determination of enzyme activity}

Nitrate Reductase. The nitrate reductase activity (NRA) was determined following the protocol of Sym (1984). Briefly, fresh, chopped leaves $(0.5 \mathrm{~g})$ were added to test tubes containing phosphate buffer ( $\mathrm{pH} 7.0$ ), $0.5 \mathrm{~mL}$ of $0.02 \mathrm{M} \mathrm{KNO}_{3}, 0.5 \mathrm{~mL}$ of sulphanilamide, and $0.5 \mathrm{~mL}$ of $\mathrm{N}$-(1-naphthyl)-ethylene diamine dihydrochloride and then centrifuged for $5 \mathrm{~min}$ at $1500 \mathrm{~g}_{\mathrm{n}}$. The absorbance at $542 \mathrm{~nm}$ was measured using a set of $\mathrm{NaNO}_{2}$ standards. The activity was calculated and expressed as the amount (in micromoles) of $\mathrm{NO}_{2}$ released per gram of fresh weight per hour.

Nitrite Reductase. The nitrite reductase activity (NiRA) was calculated by the method of Ramarao et al. (1983). Fresh leaves were chopped, and $0.5 \mathrm{~g}$ was added to a $25-\mathrm{mL}$ test tube wrapped with aluminium foil and containing $4.5 \mathrm{~mL}$ of phosphate buffer (pH 5.0) and $0.5 \mathrm{~mL}$ of $\mathrm{NaNO}_{2}(0.02 \mathrm{M})$. One milliliter of extract, $0.5 \mathrm{~mL}$ of $1 \%$ sulphanilamide, and $0.5 \mathrm{~mL}$ of $0.02 \%$ aqueous solution of $\mathrm{N}$ (1-naphthyl)-ethylene diamine dihydrochloride were added to the tubes and allowed to stand for $20 \mathrm{~min}$ for color development. The optical density was measured at $540 \mathrm{~nm}$ with a spectrophotometer, and a standard curve was developed with $\mathrm{NaNO}_{2}$. The activity was calculated and expressed as the amount (in micromoles) of $\mathrm{NO}_{2}$ released per gram of fresh weight per hour.
For estimating antioxidant enzyme activity, fresh leaves $(0.5 \mathrm{~g})$ were ground in an ice-cooled tissue grinder in $5 \mathrm{~mL}$ of $50 \mathrm{~mm}$ cooled phosphate buffer ( $\mathrm{pH} 7.8)$. The homogeneous mixture was centrifuged at $1500 g_{\mathrm{n}}$ for $20 \mathrm{~min}$ at $4{ }^{\circ} \mathrm{C}$. The supernatant was used to determine the activities of the following enzymes.

SuPEROXIDE DISMUTASE. The activity of SOD was analyzed according to the protocol of Giannopolitis and Ries (1977) by calculating its potential to hinder the photoreduction of nitroblue tetrazolium (NBT). The reaction solution $(3 \mathrm{~mL})$ contained $50 \mathrm{~mm}$ NBT, $1.3 \mathrm{~mm}$ riboflavin, $13 \mathrm{~mm}$ methionine, $75 \mathrm{~mm}$ (ethylene diaminetetraacetic acid) EDTA, $50 \mathrm{~mm}$ phosphate buffer (pH 7.8), and $20 \mathrm{~mL}$ of enzyme extract. The absorbance of the solution was measured at $560 \mathrm{~nm}$ using a spectrophotometer (model 650; Hitachi, Tokyo, Japan). One unit of SOD activity was defined as the amount of enzyme that restricted 50\% of the NBT photo decline.

Catalase and peroxidase. The CAT and POD activities were measured by the procedure of Chance and Maehly (1955) with some alterations. The CAT reaction solution $(3 \mathrm{~mL})$ comprised $50 \mathrm{~mm}$ phosphate buffer ( $\mathrm{pH} 7.0$ ), $5.9 \mathrm{~mm} \mathrm{H}_{2} \mathrm{O}_{2}$, and $0.1 \mathrm{~mL}$ of enzyme extract. The changes in absorbance of the reaction solution were recorded every $20 \mathrm{~s}$ at $240 \mathrm{~nm}$. One unit of CAT activity was defined as an absorbance change of 0.01 units per min. The POD reaction solution $(3 \mathrm{~mL})$ comprised $50 \mathrm{~mm}$ phosphate buffer (pH 5.0), $20 \mathrm{~mm}$ guaiacol, $40 \mathrm{~mm} \mathrm{H}_{2} \mathrm{O}_{2}$, and $0.1 \mathrm{~mL}$ of enzyme extract. Changes in the absorbance of the reaction solution were measured every $20 \mathrm{~s}$ at $470 \mathrm{~nm}$. One unit of POD activity was defined as an absorbance change of 0.01 units per min. The activity of each enzyme was expressed on the basis of protein content.
A

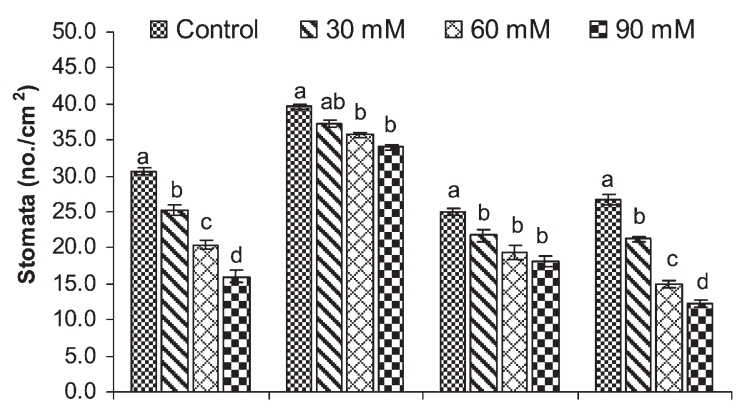

C

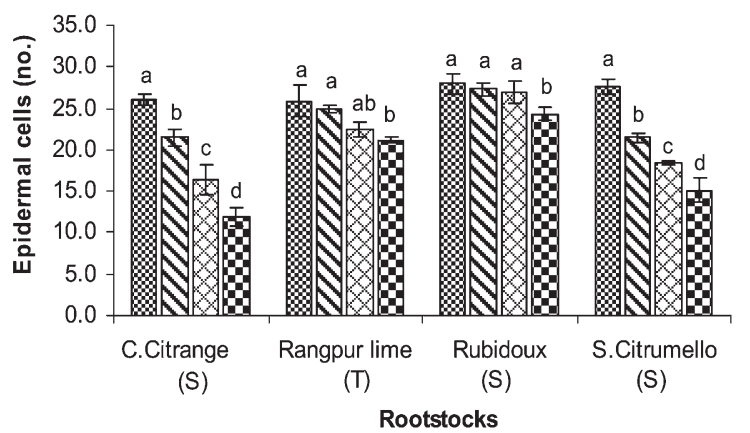

B

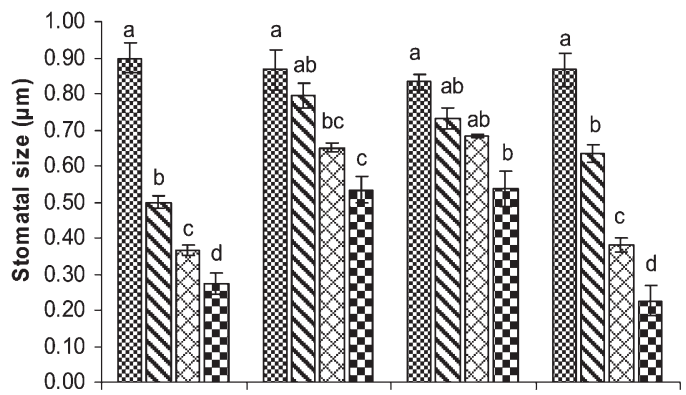

D

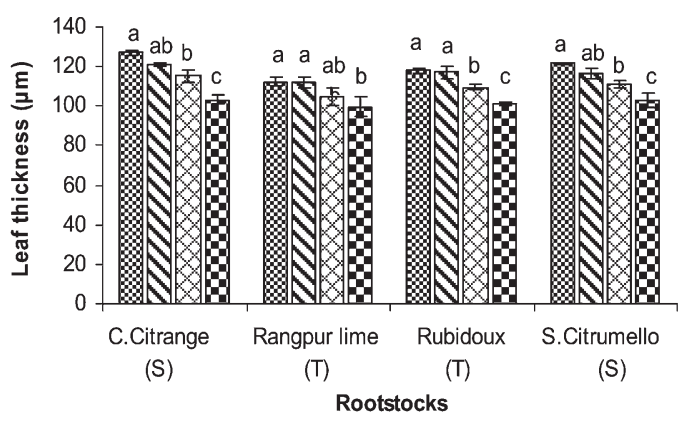

Fig. 2. Effect of salt stress $(0,30,60$, or $90 \mathrm{~mm} \mathrm{NaCl}$ applied in the irrigation water) on leaf attributes of two salt-tolerant (T) and two salt-sensitive (S) cultivated citrus rootstocks: number of stomata $(\mathbf{A})$, stomatal size $(\mathbf{B})$, number of epidermal cells $(\mathbf{C})$, and leaf thickness $(\mathbf{D})$. Each value represents the mean of five replicates \pm SE. Two-way analysis of variance for the interaction of cultivar $\times$ treatment and main effects of cultivar and treatment were significant at $P<0.05$. Letters within a cultivar represent mean separation comparison using Tukey's honestly significant difference (HSD) test (C. citrange $=$ Carrizo citrange, $\mathrm{S}$. citrumello $=$ Sanchton citrumello). 
$\mathrm{NA}^{+}, \mathrm{K}^{+}, \mathrm{CA}^{2+}$, And $\mathrm{MG}^{2+}$ Determination. Dried, ground plant material $(0.5 \mathrm{~g})$ from roots, shoots, and leaves was digested with concentrated sulphuric acid $(5 \mathrm{~mL})$ and $\mathrm{H}_{2} \mathrm{O}_{2}$ (35\%, $0.5 \mathrm{~mL}$ per digestion tube) as described by Wolf (1990). The digested samples were then analyzed for $\mathrm{Na}^{+}$and $\mathrm{K}^{+}$by a flame photometer (Jenway PFP-7; Keison Products, Chelmsford, U.K.). A graded series of standards (ranging from 10 to $100 \mathrm{mg} \cdot \mathrm{L}^{-1}$ ) of $\mathrm{Na}^{+}$and $\mathrm{K}^{+}$was prepared, and standard curves were calculated. The values of $\mathrm{Na}^{+}$and $\mathrm{K}^{+}$from the flame photometer were compared with the standard curves, and the original quantities were computed. $\mathrm{Ca}^{2+}$ and $\mathrm{Mg}^{2+}$ were determined titrimetrically using an EDTA solution $(0.01 \mathrm{~N})$ as a standard solution and eriochrome black $\mathrm{T}$ and calcon as indicators as described by Bower and Hatcher (1962).

Chloride. To prepare extracts containing chloride, ground material $(1 \mathrm{~g})$ was heated with $20 \mathrm{~mL}$ of distilled water in $20-\mathrm{mL}$ test tubes, which were placed in an oven at $65{ }^{\circ} \mathrm{C}$ overnight. Chloride extracts were filtered using Whatman-40 filter paper, and the chloride concentration was determined using a chloride analyser (Model 920; Corning, Achem, Germany).

\section{Statistical analysis}

The experimental units were arranged in the greenhouse according to a randomized complete design. All statistical analyses were conducted using Statistix (Version 8.1; Analytical Software, Spotfire, Greece). For all measured parameters, a two-way analysis of variance was conducted to determine the significant main effects of cultivar and salt treatment as well as their interaction (cultivar-by-salt treatment). For a given measured parameter, and within each cultivar, significant salt treatment responses were assessed using the Tukey's honestly significant difference test. Finally, the correlation coefficients
A

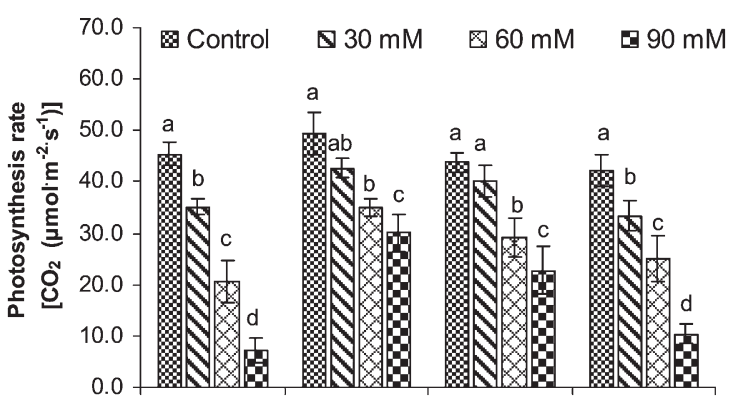

C

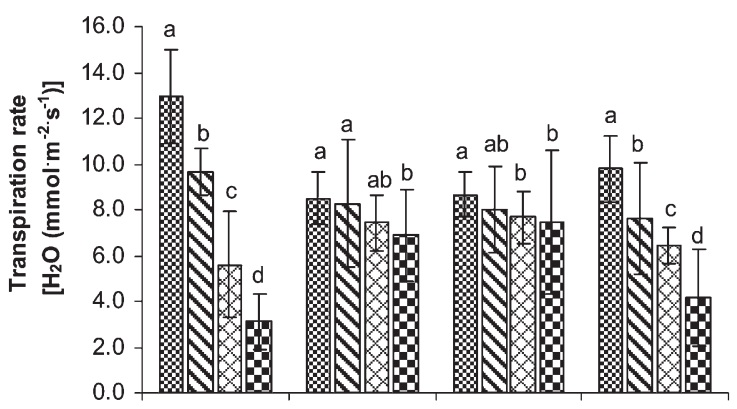

E

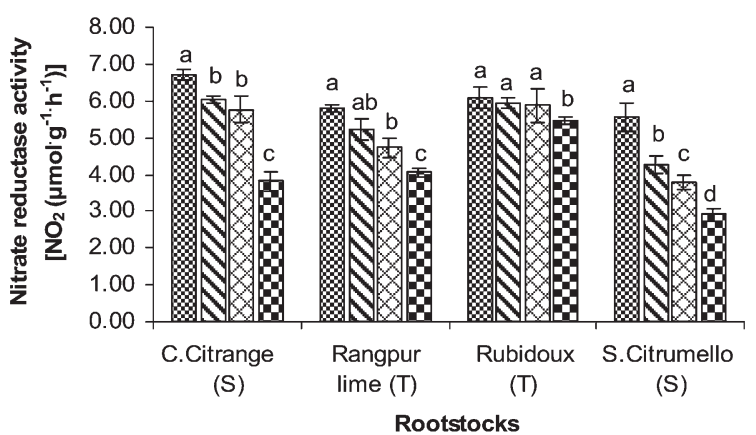

B

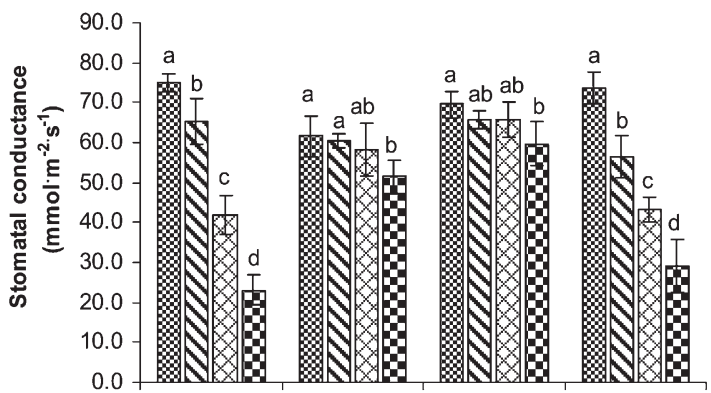

D

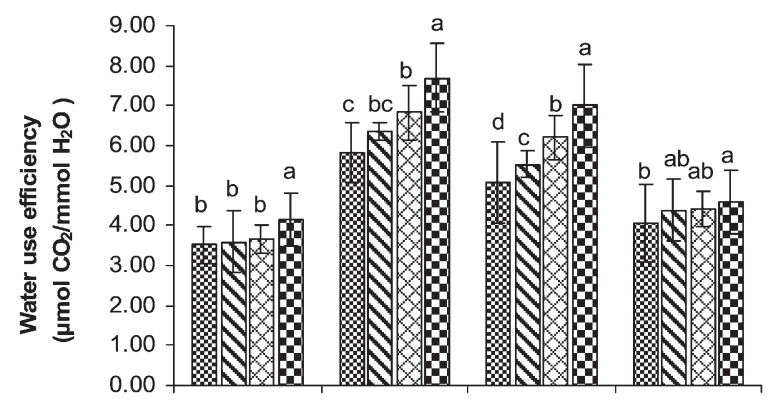

$\mathbf{F}$

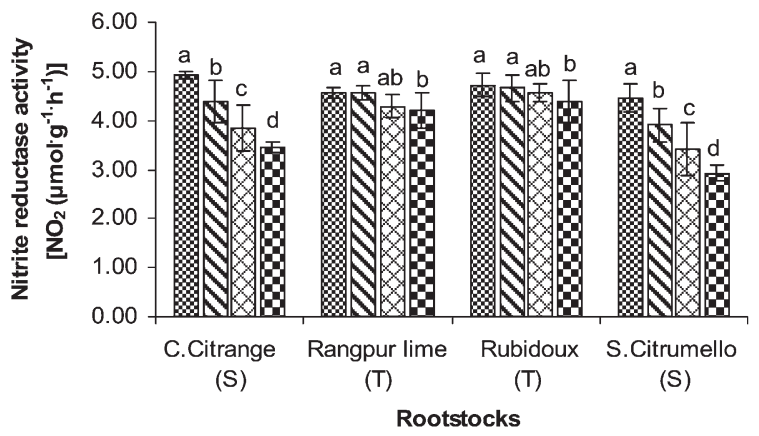

Fig. 3. Effect of salt stress $(0,30,60$, or $90 \mathrm{~mm} \mathrm{NaCl}$ applied in the irrigation water) on photosynthesis parameters of two salt-tolerant (T) and two salt-sensitive (S) cultivated citrus rootstocks: photosynthesis $(\mathbf{A})$, stomatal condutance $\left(g_{\mathrm{S}}\right)(\mathbf{B})$, transpiration $(\mathbf{C})$, water use efficiency $(\mathbf{D})$, nitrate reductase activity $(\mathbf{E})$, and nitrite reductase activity $(\mathbf{F})$. Each value represents the mean of five replicates \pm SE. Two-way analysis of variance for the interaction of cultivar $\times$ treatment and main effects of cultivar and treatment were significant at $P<0.05$. Letters within a cultivar represent mean separation comparison using Tukey's honestly significant difference (HSD) test $(\mathrm{C}$. citrange $=$ Carrizo citrange, $\mathrm{S}$. citrumello $=$ Sanchton citrumello). 
measuring the degree of linear relationship between two given variables were calculated for several parameters (plant dry weight, $\mathrm{P}_{\mathrm{n}}, g_{\mathrm{S}}, E$, number of stomata, stomatal size, WUE, SOD, POD, CAT, leaf $\mathrm{Na}^{+}$, and leaf $\mathrm{Cl}^{-}$) using Pearson productmoment correlation coefficients. Table 1 was prepared using the data from all four cultivars.

\section{Results}

Effect of NaCl Stress on Plant biomass. Salinity caused a significant $(P<0.05)$ reduction in root and shoot fresh and dry biomass, but this effect was more pronounced in the saltsensitive plants, Carrizo citrange and Sanchton citrumello (Fig. 1). Significant reductions in the mean percentage over the control of $4 \%, 12 \%, 18 \%$, and $43 \%$ were recorded for root fresh weight; $9 \%, 15 \%, 16 \%$, and $9 \%$ for root dry weight; $3 \%$, $4 \%, 21 \%$, and $42 \%$ for shoot fresh weight; and 10\%, 14\%, 25\%, and $24 \%$ for shoot dry weight for Rangpur lime, Rubidoux, Carrizo citrange, and Sanchton citrumello, respectively. Salt stress significantly reduced $(P<0.05)$ root and shoot lengths, but the largest percentage reductions were observed in the saltsensitive cultivars, Carrizo citrange (37\% root and 26\% shoot) and Sanchton citrumello (49\% root and 24\% shoot). Likewise, the sensitive cultivars exhibited a reduction in leaf thickness, but there was a smaller percentage reduction in the tolerant cultivars, especially Rangpur lime (Fig. 2).

EFFect of SALt STRESS ON PHYSIOLOGICAL ATtRibutes. The number of stomata and epidermal cells generally declined with an increase in $\mathrm{NaCl}$ stress (Fig. 2). Tolerant rootstocks exhibited a smaller percentage reduction $(10 \%$ to $21 \%$ ) with respect to the number of stomata than did sensitive cultivars (33\% to 39\% reduction compared with control plants). With respect to the number of epidermal cells, tolerant cultivars exhibited a smaller reduction (18\%) than did sensitive cultivars $(50 \%)$. Similarly, a considerable decrease in stomatal size was observed with an elevation in $\mathrm{NaCl}$ stress, but the tolerant cultivars were less adversely affected (22\% to $24 \%$ reduction) compared with the salt-sensitive rootstocks (52\% to $58 \%$ reduction).

The control plants $(0 \mathrm{~mm} \mathrm{NaCl})$ of the four cultivars exhibited similar photosynthetic activities. However, under increasing salt stress, $\mathrm{P}_{\mathrm{n}}$ was more severely impaired in the salt-sensitive cultivars ( $46 \%$ to $54 \%$ decrease over the control) compared with the salt-tolerant cultivars (27\% to $30 \%$ decrease over the control) (Fig. 3). Stomatal conductance was higher in the leaves of the salt-resistant rootstocks exposed to $90 \mathrm{~mm}$ $\mathrm{NaCl}$ ( $7 \%$ to $8 \%$ reduction compared with the control), whereas the leaves of the salt-sensitive cultivars exhibited a greater percentage reduction at $90 \mathrm{~mm}(41 \%$ to $42 \%$ compared with the control). The plants exposed to $\mathrm{NaCl}$ had a greater variation in transpiration rate compared with those grown under nonstressed conditions. The stressed plants of Rubidoux maintained a relatively high transpiration rate at $90 \mathrm{~mm} \mathrm{NaCl}$ compared with $0 \mathrm{~mm} \mathrm{NaCl}$ (11\% reduction), whereas Carrizo citrange exhibited the greatest percentage reduction in transpiration [53\% (Fig. 3)]. The plants exposed to $\mathrm{NaCl}$ exhibited a greater WUE than the plants grown under non-saline conditions. It was observed that the stress-tolerant cultivars had a greater WUE than did salt-sensitive cultivars (Fig. 3). A strong correlation was observed between physiological attributes $\left(\mathrm{P}_{\mathrm{n}}, g_{\mathrm{S}}\right.$, number of stomata, stomatal size $)$ and growth (plant fresh and dry weights) (Table 1).
EFFECT OF SALT STRESS ON ENZYMATIC ACTIVITIES. NRA and NiRA decreased as the $\mathrm{NaCl}$ concentration increased (Fig. 3). However, a higher leaf NRA and NiRA significantly differentiated the salt-tolerant rootstocks from salt-sensitive rootstocks. When comparing the plants treated with $90 \mathrm{~mm}$ $\mathrm{NaCl}$ with the control plants, the tolerant cultivars had lower percentage decreases in NRA ( $5 \%$ to $19 \%)$ and NiRA $(2 \%$ to $5 \%$, whereas the sensitive cultivars exhibited greater percentage decreases in NRA (23\% to $33 \%)$ and NiRA $(21 \%$ to $23 \%$ ). Salinity also increased antioxidant activity (SOD, POD, and CAT), but sensitive rootstocks were less affected (Fig. 4). It is clear that the SOD, POD, and CAT activities were highest in the plants exposed to $90 \mathrm{~mm} \mathrm{NaCl}$ stress compared with the control plants. The greatest percentage

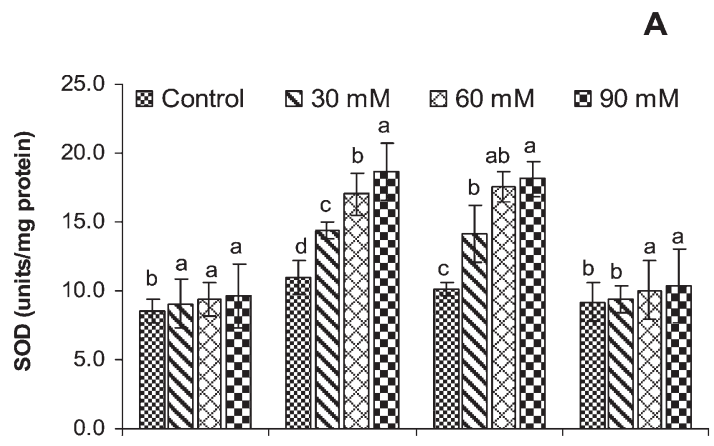

B

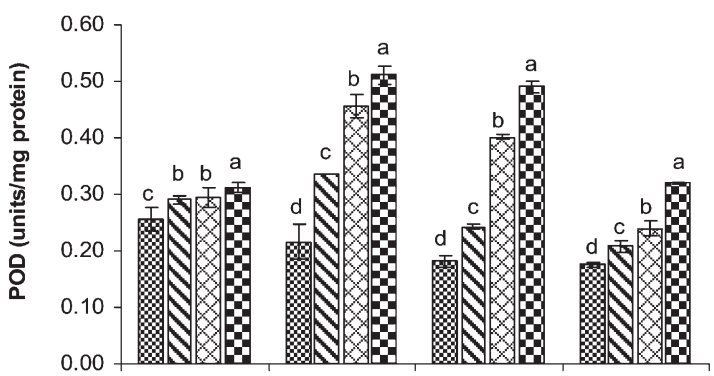

C

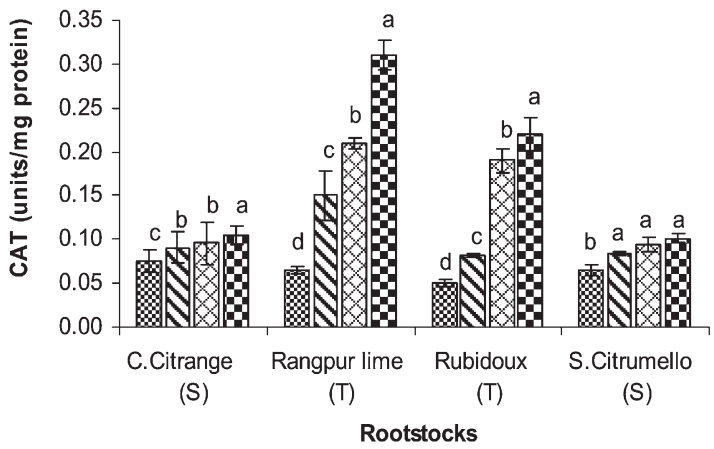

Fig. 4. Effect of salt stress $(0,30,60$, or $90 \mathrm{~mm} \mathrm{NaCl}$ applied in the irrigation water) on antioxidant enzyme expression of two salt-tolerant $(\mathrm{T})$ and two saltsensitive (S) cultivated citrus rootstocks: superoxide dismutase (A), peroxidase $(\mathbf{B})$, and catalase $(\mathbf{C})$. Each value represents the mean of five replicates \pm SE. Two-way analysis of variance for the interaction of cultivar $\times$ treatment and main effects of cultivar and treatment were significant at $P<0.05$. Letters within a cultivar represent denote mean separation comparison using Tukey's honestly significant difference (HSD) test (C. citrange = Carrizo citrange, $\mathrm{S}$. citrumello $=$ Sanchton citrumello) . 
increase (at $90 \mathrm{~mm}$ vs. control) was found for the tolerant rootstocks (31\% to $64 \%$ increase), whereas for the sensitive rootstocks, the percentage increase was only $5 \%$ to $13 \%$. A strong correlation was found between antioxidant activities and growth attributes (Table 1).

EFFECT OF SALT STRESS ON ION CONTENT. Leaf $\mathrm{Na}^{+}$and $\mathrm{Cl}^{-}$ concentrations were significantly elevated with increased $\mathrm{NaCl}$ concentrations (Fig. 5). With respect to the leaves, compared with the control treatments, the salt-tolerant cultivars exhibited a percentage increase of $60 \%$ to $156 \%$ for $\mathrm{Na}^{+}$and $12 \%$ to $33 \%$ for $\mathrm{Cl}^{-}$, whereas the salt-sensitive cultivars exhibited a percentage increase of $204 \%$ to $567 \%$ for $\mathrm{Na}^{+}$and $150 \%$ to $534 \%$ for chloride $\mathrm{Cl}^{-}$. Shoot $\mathrm{Na}^{+}$and $\mathrm{Cl}^{-}$concentrations exhibited a pattern similar to that found in the leaves (Fig. 5). However, in roots, the salt-tolerant rootstocks exhibited a larger percentage increase in $\mathrm{Na}^{+}(154 \%$ to $592 \%)$ and $\mathrm{Cl}^{-}(99 \%$ to $258 \%)$ compared with the control, whereas the salt-sensitive cultivars exhibited a smaller percentage increase in the root concentration of $\mathrm{Na}^{+}$(21\% to $\left.134 \%\right)$ and $\mathrm{Cl}^{-}(20 \%$ to $58 \%$ ) (Fig. 5). Overall, it was observed that the salt-tolerant cultivars showed a maximum concentration of $\mathrm{Na}^{+}$and $\mathrm{Cl}^{-}$in the roots, whereas the salt-sensitive cultivars showed a maximum concentration of $\mathrm{Na}^{+}$and $\mathrm{Cl}^{-}$in their leaves followed by in their shoots. Salinity caused a significant $(P<0.05)$ reduction in root, shoot, and leaf $\mathrm{K}^{+}, \mathrm{Ca}^{2+}$, and $\mathrm{Mg}^{2+}$ in each of the four genotypes tested (Fig. 6). Rangpur lime and Rubidoux exposed to $90 \mathrm{~mm}$ had greater concentrations of $\mathrm{K}^{+}, \mathrm{Ca}^{2+}$, and $\mathrm{Mg}^{2+}$ in their leaves and shoots than did salt-stressed Carrizo citrange and Sanchton citrumello. Salt-tolerant and salt-sensitive cultivars exhibited a specific pattern in the roots different from that found in the leaves and shoots. Overall, compared with the sensitive rootstocks, tolerant rootstocks exhibited a smaller reduction in leaf and $\operatorname{root} \mathrm{K}^{+}, \mathrm{Ca}^{2+}$,

A
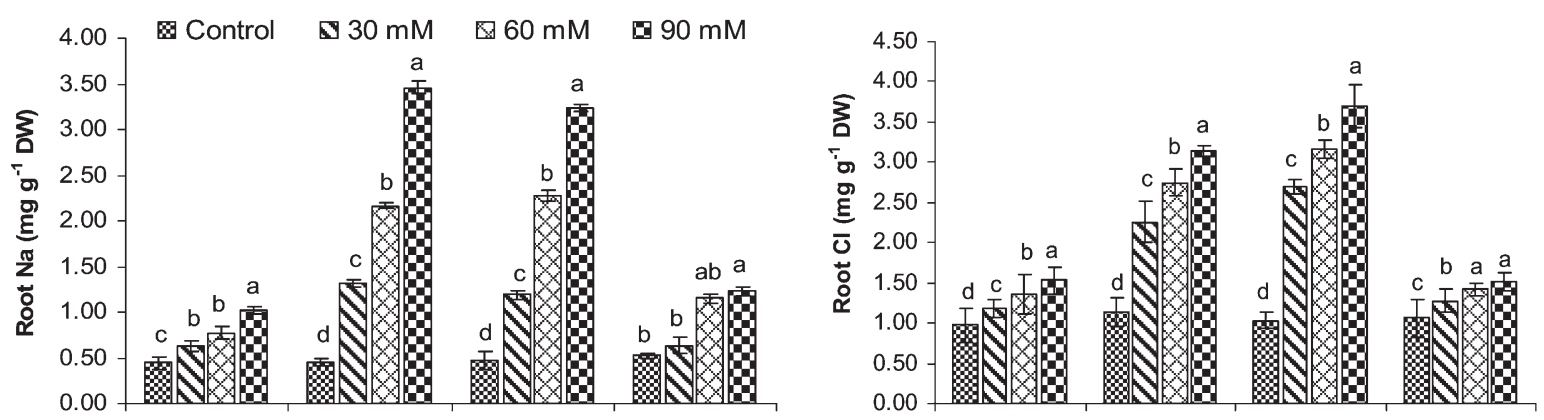

C
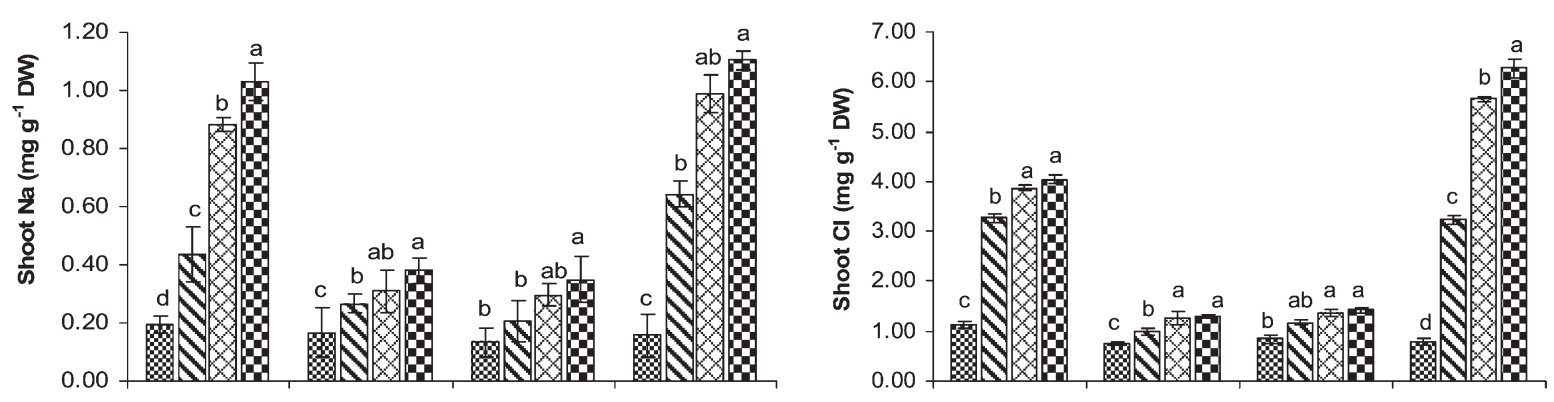

$\mathbf{E}$
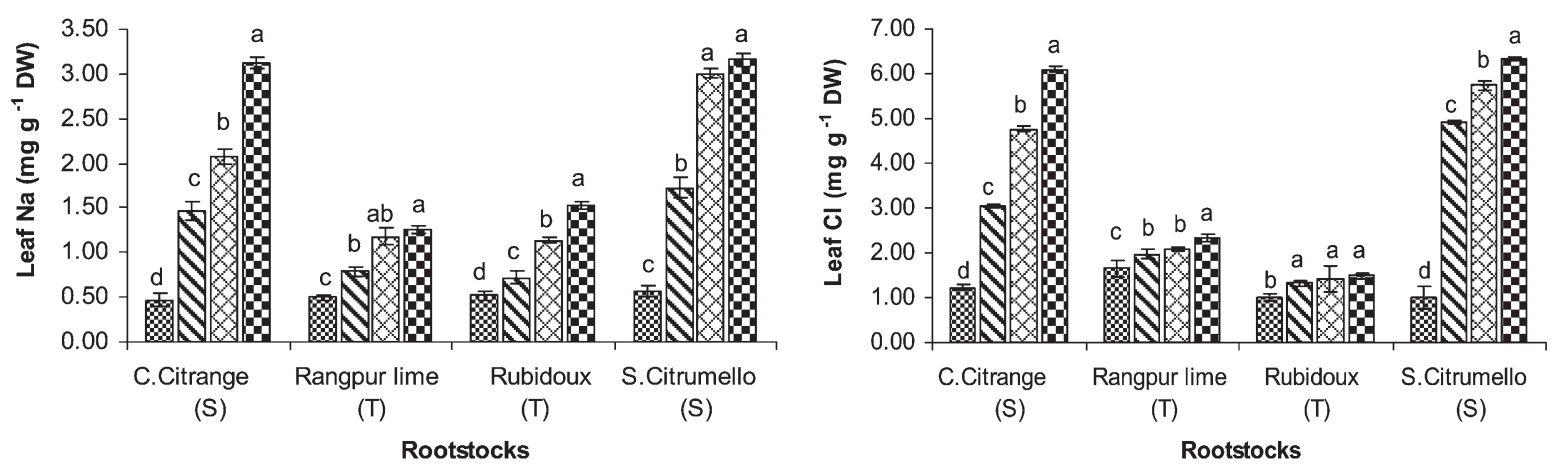

Fig. 5. Effect of salt stress $(0,30,60$, or $90 \mathrm{~mm} \mathrm{NaCl}$ applied in the irrigation water) on tissue sodium and chloride contents of two salt-tolerant (T) and two saltsensitive (S) cultivated citrus rootstocks: root sodium $(\mathrm{Na})(\mathbf{A})$, root chloride $(\mathrm{Cl})(\mathbf{B})$, shoot $\mathrm{Na}(\mathbf{C})$, shoot $\mathrm{Cl}(\mathbf{D})$, leaf $\mathrm{Na}(\mathbf{E})$, and leaf $\mathrm{Cl}(\mathbf{F})$. Each value represents the mean of five replicates $\pm \mathrm{SE}$. Two-way analysis of variance for the interaction of cultivar $\times$ treatment and main effects of cultivar and treatment were significant at $P<0.05$. Letters within a cultivar represent mean separation comparison using Tukey's honestly significant difference (HSD) test (C. citrange $=$ Carrizo citrange, S. citrumello $=$ Sanchton citrumello). 

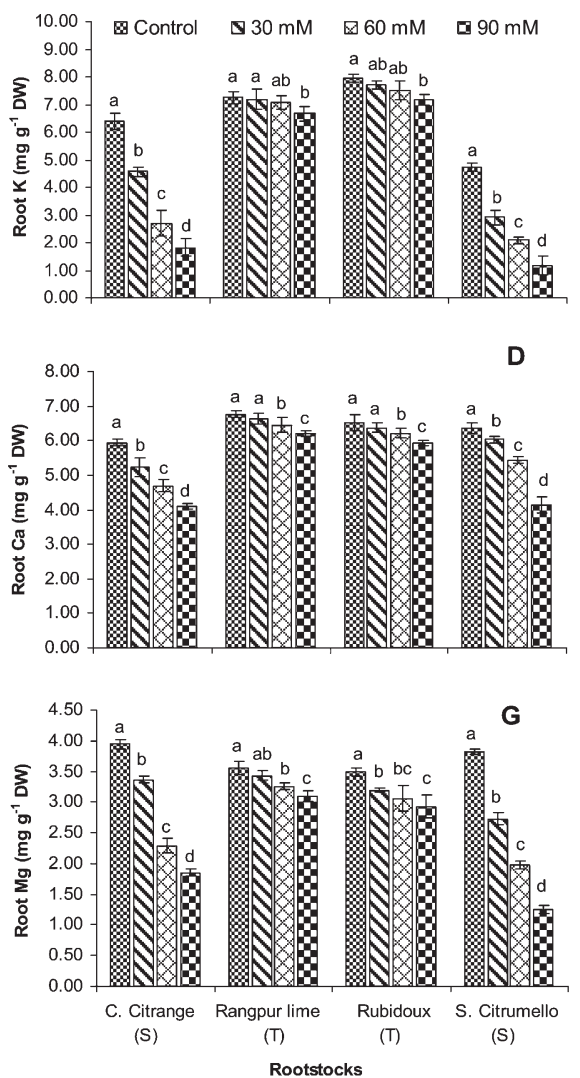

C
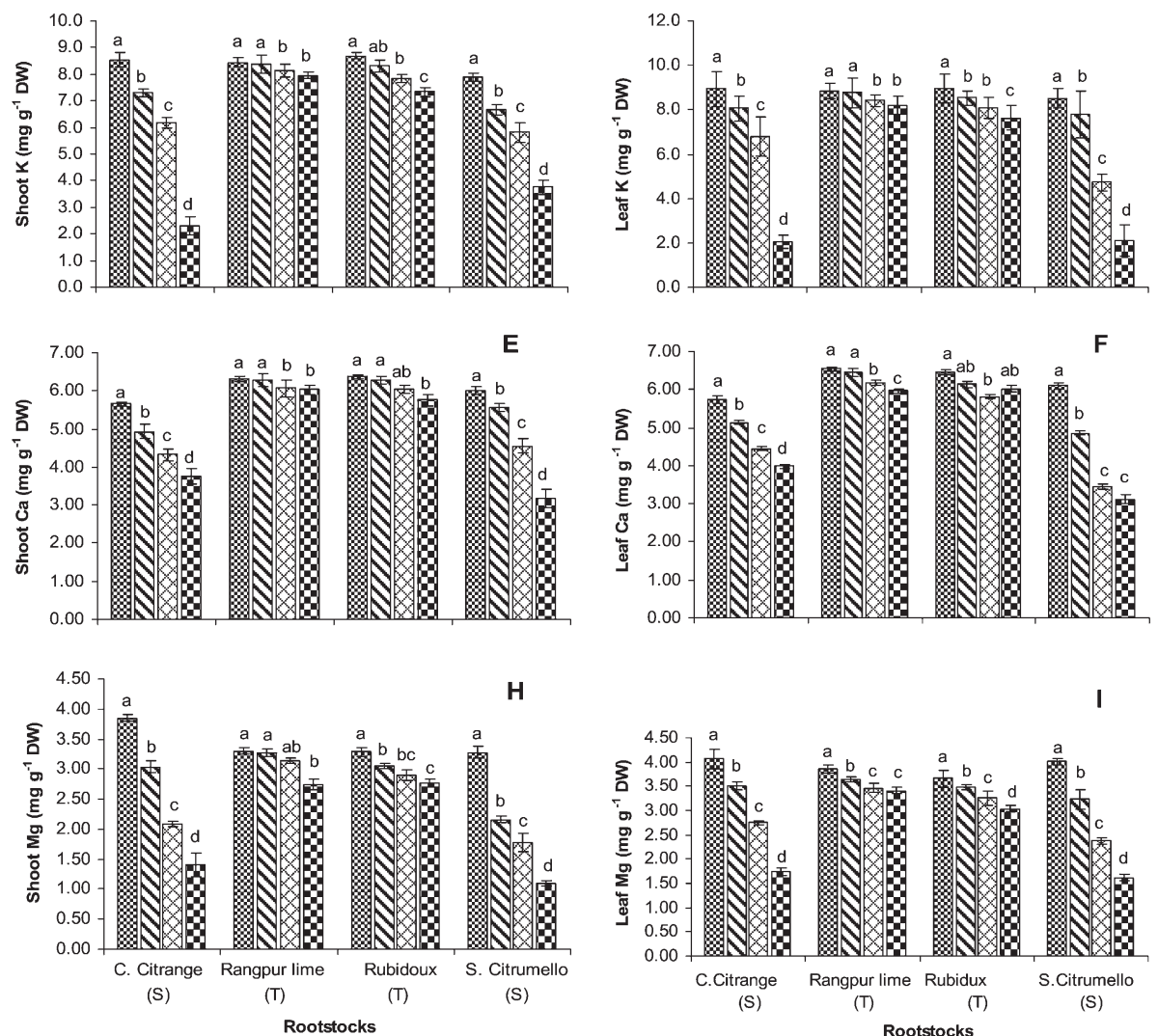

I

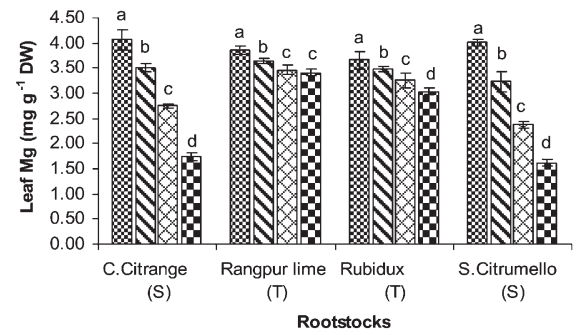

Fig. 6. Effect of salt stress $(0,30,60$, or $90 \mathrm{~mm} \mathrm{NaCl}$ applied in the irrigation water) on potassium (K), calcium (Ca), and magnesium (Mg) tissue content of two salttolerant (T) and two salt-sensitive (S) cultivated citrus rootstocks: root $\mathrm{K}(\mathbf{A})$, shoot $\mathrm{K}(\mathbf{B})$, leaf $\mathrm{K}(\mathbf{C})$, root $\mathrm{Ca}(\mathbf{D})$, shoot $\mathrm{Ca}(\mathbf{E})$, and leaf Ca (F). Each value represents the mean of five replicates \pm SE. Two-way analysis of variance for the interaction of cultivar $\times$ treatment and main effects of cultivar and treatment were significant at $P<0.05$. Letters within a cultivar represent mean separation comparison using Tukey's honestly significant difference (HSD) test (C. citrange $=$ Carrizo citrange, $\mathrm{S}$. citrumello $=$ Sanchton citrumello).

and $\mathrm{Mg}^{2+}$ concentrations in response to an increased salt concentration.

\section{Discussion}

In this study, the reductions in growth attributes could have been the result of a decline in the water potential $\psi_{\mathrm{w}}$ in response to salt stress, which could reduce cell elongation and cell division. The results regarding growth attributes and plant biomass reported in the current study are in accordance with the findings of Ashraf and Ahmad (2000) and Ltaief et al. (2007). In the present investigation, salt stress induced a significant reduction in various physiological attributes such as the number of stomata, the number of epidermal cells, $\mathrm{P}_{\mathrm{n}}, g_{\mathrm{S}}$, and $E$. The decline in these physiological traits may be associated with the combined effect of different factors, i.e., a reduction in the leaf calcium and potassium contents and a reduction in the number and size of stomata. The reduction in stomatal size in this study may be the result of a reduced turgidity in the guard cells attributable to a lower availability of cations such as $\mathrm{Ca}^{+}$and $\mathrm{K}^{+}$ that regulate stomatal opening and closing (Iljin, 1957). The mechanisms of how salt stress affects the number of stomata and epidermal cells have been not reported in the literature but may relate to the degree to which water stress limits cell division during organ development. However, there are similar reports that have found a reduction in the number of stomata and epidermal cells under stressed conditions (Hwang and Chen, 1995; Martins and Castro, 1999). Photosynthetic activity is directly dependent on gas exchange through the stomata, and any disturbances in the stomata have a negative effect on $\mathrm{P}_{\mathrm{n}}$. In our investigation, salt stress negatively affected the $\mathrm{Ca}^{2+}$ and $\mathrm{K}^{+}$ content, stomatal number, and stomatal size; therefore, the decrease in the photosynthetic parameters $\left(\mathrm{P}_{\mathrm{n}}, g_{\mathrm{S}}\right.$, and $\left.E\right)$ may have been the result of these factors. Accordingly, the $\mathrm{Ca}^{2+}$ and $\mathrm{K}^{+}$content, stomatal number, and stomatal size were less adversely affected in the tolerant rootstock cultivars, which may have resulted in more efficient $\mathrm{P}_{\mathrm{n}}, g_{\mathrm{S}}$, and $E$, consequently leading to better growth and development than the salt-sensitive cultivars. The results regarding $\mathrm{Pn}, g_{\mathrm{S}}$, and $E$ confirmed the findings of Gorai et al. (2010), Hayat et al. (2010), and Moya et al. (2003). Our results regarding WUE are in accordance with those of Grewal (2010) and Hessini et al. (2009). A strong correlation was observed between $P_{n}$ and WUE as indicated in Table 1.

With regard to NRA, we found that the tolerant cultivars were less affected by increases in $\mathrm{NaCl}$ compared with the sensitive cultivars. Similarly, Khan et al. (1990) have also observed that NRA is more prominently reduced in susceptible Sorghum bicolour cultivars than in tolerant cultivars under saline conditions. Very little information is available on the response of NiRA to salinity; however, it has been reported that 
a reduction in NiRA may be the result of lower substrate $\left(\mathrm{NO}_{2}{ }^{-}\right)$ availability. Because $\mathrm{NO}_{2}^{-}$is a product of NRA activity, a decrease in NRA activity could reduce NiRA as well.

In the current study, salt stress increased the enzyme activities of SOS, POD, and CAT in all genotypes, but the most substantial increases were found in the salt-tolerant rootstocks (Fig. 4). The high antioxidant activities in the tolerant rootstocks could be considered a major reason for better performance under saline conditions. The higher antioxidant activity would decrease lipid peroxidation as a result of ROS. The resultant greater membrane integrity would enhance the efficiency of photosynthesis and dry matter formation. The findings of the present study are in agreement with those of Heidari (2010). A strong correlation was noted between antioxidant enzymes and plant dry matter (shoot and leaves) (Table 1).

High concentrations of $\mathrm{Na}^{+}$and $\mathrm{Cl}^{-}$in the roots of salttolerant cultivars (Fig. 5) may be the result of a more selective transport of ions to upper plant parts; this could also be an adaptation to salt tolerance. Sensitive cultivars failed to restrict the transport of excessive $\mathrm{Na}^{+}$in their roots to the shoots and leaves. It has been previously reported that the tolerance of citrus rootstocks to salinity is associated with the ability to restrict, or at least reduce, the supply of $\mathrm{Na}^{+}$and $\mathrm{Cl}^{-}$ions to the shoots (Arbona et al., 2006; Moya et al., 2003), and the present study is consistent with that finding. Overall, the $\mathrm{Na}^{+}$and $\mathrm{Cl}^{-}$ content in the leaves showed a strong negative correlation with $\mathrm{P}_{n}$; therefore, the cultivars with less $\mathrm{Na}^{+}$in their leaves maintained a high $\mathrm{P}_{\mathrm{n}}$ and more dry matter (Table 1). The reduction in beneficial ions such as $\mathrm{Ca}^{2+}, \mathrm{K}^{+}$, and $\mathrm{Mg}^{2+}$ may be the result of the antagonistic effect of $\mathrm{Na}^{+}$with these ions, especially $\mathrm{Ca}^{2+}$ and $\mathrm{K}^{+}$, which has been reported by others ( $\mathrm{Hu}$ and Schmidhalter, 2005; Levy and Syvertsen, 2004; Neto and Tabosa, 2000). This major difference in ion accumulation could also be a primary reason for differentiating salt-tolerant rootstocks from salt-sensitive ones.

In summary, we found that salt stress limits rootstock growth by disturbing various morphological, physiological, and biochemical mechanisms within plant tissues. In particular, the concentration of inorganic osmolytes $\left(\mathrm{Ca}^{2+}, \mathrm{K}^{+}\right.$, and $\left.\mathrm{Mg}^{2+}\right)$ and antioxidant activities (SOD, POD, and CAT) are highly associated with the salt tolerance of citrus rootstocks. The roots of tolerant rootstocks appear to restrict the transport of ions $\left(\mathrm{Na}^{+}\right.$and $\left.\mathrm{Cl}^{-}\right)$to shoots and leaves. These divergent patterns of antioxidant enzyme activity and ion accumulation may be useful as early indicators of salt tolerance for screening rootstock responses to high $\mathrm{NaCl}$.

\section{Literature Cited}

Almansa, S.M., J.A. Hernandez, A. Jimenez, M.A. Botella, and F. Sevilla. 2002. Effect of salt stress on superoxide dismutase activity in leaves of Citrus limonium in different rootstock-scion combinations. Biol. Plant. 45:545-549.

Arbona, V., A.J. Macro, D.J. Iglessias, M.F. Lopez-Clements, M. Talon, and A. Gomez-Cadnas. 2006. Carbohydrate depletion in roots and leaves of salt-affected potted Citrus clementina L. Plant Growth Regulat. 46:153-160.

Ashraf, M. and S. Ahmad. 2000. Influence of sodium chloride on ion accumulation, yield components and fibre characteristics in salttolerant and salt-sensitive lines of cotton (Gossypium hirsutum L.). Field Crops Res. 66:115-127.

Bower, C.A. and J.T. Hatcher. 1962. Characterization of salt-affected soils with respect to sodium. Soil Sci. 93:275-280.
Camara-Zapata, J.M., F. Garcia-Sanchez, V. Martinez, M. Nieves, and A. Cerda. 2004. Effect of $\mathrm{NaCl}$ on citrus cultivars. Agronomie $24: 155-160$

Chance, M. and A.C. Maehly. 1955. Assay of catalases and peroxidases. Methods Enzymol. 2:764-817.

Garcia-Sanchez, F. and J.P. Syvertsen. 2006. Salinity tolerance of Cleopatra mandarin and Carrizo citrange citrus rootstock seedling is affected by $\mathrm{CO}_{2}$ enrichment during growth. J. Amer. Soc. Hort. Sci. 131:24-31.

Garcia-Sanchez, F., J.P. Syvertsen, V. Martinez, and J.C. Melgar. 2006. Salinity tolerance of 'Valencia' orange trees on rootstocks with contrasting salt tolerance is not improved by moderate shade. J. Expt. Bot. 57:3697-3706.

Garcia-Sanchez, M.R., P. Bernet, J. Puchades, E.A. Gomez, and M.J. Asins. 2002a. Evaluation of salt tolerance of five citrus rootstocks using screening technique. Aust. J. Agr. Res. 53:653-662.

Garcia-Sanchez, F., J. Jifon, M. Carvajal, and J.P. Syvertsen. 2002b. Gas exchange, chlorophyll and nutrient contents in relation to $\mathrm{Na}^{+}$ and $\mathrm{Cl}^{-}$accumulation in 'Sunburst' mandarin grafted on different rootstocks. Plant Sci. 162:705-712.

Giannopolitis, C.N. and S.K. Ries. 1977. Superoxide dismutase I. Occurrence in higher plants. Plant Physiol. 59:309-314.

Gorai, M., M. Ennajeh, H. Khemira, and M. Neffati. 2010. Combined effect of NaCl-salinity and hypoxia on growth, photosynthesis, water relations and solute accumulation in Phragmites australis plants. Flora 205:462-470.

Grewal, H.S. 2010. Water uptake, water use efficiency, plant growth and ionic balance of wheat, barley, canola and chickpea plants on a sodic vertosol with variable subsoil $\mathrm{NaCl}$ salinity. Agr. Water Mgt. 97:148-156.

Hayat, S., S.A. Hasan, M. Yusuf, Q. Hayat, and A. Ahmad. 2010. Effect of 28- homobrassinolide on photosynthesis, fluorescence and antioxidant system in the presence or absence of salinity and temperature in Vigna radiata. Environ. Exp. Bot. 69:105-112.

Heidari, M. 2010. Nucleic acid metabolism, proline concentration and antioxidants enzyme activity in canola (Brassica napus L.) under salinity stress. Agr. Sci. China 9:504-511.

Hernandez, J.A., A. Campillo, A. Jimenez, J.J. Alarcon, and F. Sevilla. 1999. Response of antioxidant systems and leaf water relations to $\mathrm{NaCl}$ stress in pea plants. New Phytol. 141:241-251.

Hessini, K., J.B. Martinez, M. Gandour, A. Albouchi, A. Soltani, and C. Abdelly. 2009. Effect of water stress on growth, osmotic adjustment, cell wall elasticity and water-use efficiency in Spartina alterniflora. Environ. Exp. Bot. 67:312-319.

Hoagland, D.R. and D.J. Arnon. 1950. The water culture method for growing plants without soil. California Agr. Expt. Sta. Circ. 347.

$\mathrm{Hu}, \mathrm{Y}$. and V. Schmidhalter. 2005. Drought and salinity: A comparison of their effects on mineral nutrition of plants. J. Plant Nutr. Soil Sci. 168:541-549.

Hwang, Y.H. and S.C. Chen. 1995. Anatomical responses in Kandelia candel (L.) druce seedlings growing in the presence of different concentrations of NaCl. Bot. Bull. Acad. Sin. 36:181-188.

Iljin, W.S. 1957. Drought resistance in plants and physiological processes. Annu. Rev. Plant Physiol. 8:257-274.

Khan, A.H., M.Y. Ashraf, and A.R. Azmi. 1990. Effect of $\mathrm{NaCl}$ on growth and nitrogen metabolism of sorghum. Acta Physiol. Plant. 12:233-238.

Levy, Y. and J.P. Syvertsen. 2004. Irrigation water quality and salinity effects in citrus trees. Hort. Rev. 30:37-82.

Ltaief, B., B. Sifi, M. Zaman-Allah, J. Drevon, and M. Lachaal. 2007. Effect of salinity on root-nodule conductance to the oxygen diffusion in the Cicer arietinum-Mesorhizobium ciceri symbiosis. J. Plant Physiol. 164:1028-1036.

Martins, M.B.G. and P.R.C. Castro. 1999. Growth regulators and tomato leaf anatomy (Lycopersicon esculentum Mill.) cv. Angela Gigante. Scientia Agricola 56:693-703.

McCord, J.M. 2000. The evolution of free radicals and oxidative stress. Amer. J. Med. 108:652-659. 
McCue, A.M. and A.D. Hanson. 1990. Drought and salt tolerance: Toward understanding and application. Trends Biotechnol. 8:358-362. Moya, J.L., A. Gomez-Cadenas, E. Primo-Millo, and M. Talon. 2003. Chloride absorption in salt-sensitive Carrizo citrange and salt tolerant Cleopatra mandarin citrus rootstocks is linked to water use. J. Expt. Bot. 54:825-833.

Munns, R. and R.A. James. 2003. Screening methods for salt tolerance: A case study with tetraploid wheat. Plant Soil 253:201-218.

Neto, A.A.D. and J.N. Tabosa. 2000. Salt stress in maize seedlings: II. Distribution of cationic macronutrients and its relation with sodium. Revista Brasileira de Engenharia Agrícola e Ambiental 4:165-171.

Noreen, Z. and M. Ashraf. 2009. Assessment of variation in antioxidative defense system in salt treated pea (Pisum sativum) cultivars and its putative use as salinity tolerance markers. J. Plant Physiol. 166:1764-1774.

Rachmilevitch, S., A.B. Cousins, and A.J. Bloom. 2004. Nitrate assimilation in plants shoots depends on photorespiration. Proc. Natl. Acad. Sci. USA 101:11506-11510.

Ramarao, C.S., V.H. Patil, B.D. Dhak, and S.B. Kadrekar. 1983. A simple in vivo method for the determination of nitrite reductase activity in rice roots. Zentrum Pflanzen Physiological 109:81-85.
Raveh, E. and Y. Levy. 2005. Analysis of xylem water as an indicator of current chloride uptake status in citrus trees. Sci. Hort. 103:317327.

Romero-Aranda, R., J.L. Moya, F.R. Tadeo, F. Legaz, and E. PrimoMillo. 1998. Physiological and anatomical disturbances induced by chloride salts in sensitive and tolerant citrus: Beneficial and detrimental effects of cations. Plant Cell Environ. 21:1243-1253.

Sairam, R.K., G.C. Srivastava, S. Agarwal, and R.C. Meena. 2005. Differences in antioxidant activity in response to salinity stress in tolerant and susceptible wheat genotypes. Biol. Plant. 49:85-91.

Sym, G.J. 1984. Optimization of the in vivo assay conditions for nitrate reductase in barley (Hordeum vulgare L. cv. irgri). J. Food Sci. Agr. 35:725-730

Waqar, A., M.A. Nawaz, M.A. Iqbal, and M.M. Khan. 2007. Effect of different rootstocks on plant nutrient status and yield in Kinnow mandarin (Citrus reticulata Blanco). Pak. J. Bot. 39:1779-1786.

Wolf, B. 1990. A comparative system of leaf analysis and its use for diagnosing nutrient status. Commun. Soil Sci. Plant Anal. 13:10531059 .

Zekri, M. 2004. Strategies to manage salinity problem in citrus. Proc. Intl. Soc. Citriculture 2:639-643. 